\title{
SZÁMÍTÓGÉPEK HARDVERPARAMÉTEREINEK OSZTÁLYOZÁSA AZ AUTOMATIKUS REGISZTRÁLHATÓSÁG ALAPJÁN
}

\section{COMPUTER HARDWARE STATE PARAMETER CLASSIFICATION BASED ON REGISTRATION AUTOMATION POSSIBILITIES}

\author{
Vekov Géza \\ Sapientia EMTE, Müszaki és Humántudományok Kar, Matematika-Informatika tan- \\ szék, Cím: 540485, Románia, Marosvásárhely/Koronka, Segesvári út, 1C; Telefon / \\ Fax:+40-265-206210,vgeza@ms.sapientia.ro
}

\begin{abstract}
The functional status and performance of a technical system can be described with it's status descriptor list. The registration of these can be accomplished automatically, semi-automatically or manually. This case study presents a classification of the state parameters list of a personal computer (PC) based on the aforementioned categorization. We try to define a usable scheme for separating the parameters using software automation techniques, hardware standards information and empirical observations regarding to the reliability of collected data.
\end{abstract}

Keywords: hardware asset management, state parameters, registration, automation.

\section{Összefoglalás}

A technikai rendszerek funkcionális és általános állapotának megfigyelésére és követésére az állapotleíró paraméterek követése szükséges. Ezek regisztrálása adatgyüjtés, elemzés vagy nyilvántartás céljára automatizáltan, félig automatizáltan vagy manuálisan lehetséges. A dolgozat egy esettanulmány, mely a személyi számítógépek -, mint technikai rendszerek, - állapotleíróinak regisztrálhatóságával foglalkozik a fent említett osztályozás alapján. Az osztályba sorolás érdekében szoftveres automatizálási módszereket, gyártási standardok által szolgáltatott információkat és a paraméteradatok megbízhatóságára vonatkozó empirikus megfigyeléseket használunk fel.

Kulcsszavak: hardver komponens nyilvántartás, állapotleiró paraméter, regisztrálás, automatizálás.

\section{Bevezetés}

Vekov és Pokorádi munkájában [1] a technikai rendszerek állapotleíró paramétereinek regisztrálásának automatizálhatóság szerinti osztályozását írja le. Pokorádi megfogalmazásában a technikai rendszer állapota, illetve a benne lejátszódó folyamat a be- és kimenő valamint a belső jellemzőkkel írható le [2]. Előző munkáinkban $[1,3]$ már feldolgoztuk a számítógépek hardver-komponenseinek egy nyilvántartási rendszerbe való összegyüjtését, kitérve a specifikus adatgyüjtési módozatokra. Jelen dolgozat egy esettanulmány, melyben a fent említett paraméter-osztályozási módszerrel 
személyi számítógépek ( $\mathrm{PC}, \mathrm{x} 86$, x64 platform) - mint technikai rendszerek - hardveradatainak automatikus regisztrálási lehetőségeit elemezzük. A cél egy minél nagyobb mértékben automatizált adatgyüjtő rendszer megtervezése gyakorlati megvalósítási szempontok figyelembe vételével, és az előző tapasztalatok felhasználásával. Az automatizálhatóság fokát a paraméterek regisztrálhatóság szerinti szétválasztásával határozzuk meg. A folyamat célja az emberi tényező minél nagyobb fokú kiiktatása az adatbiztonság és konzisztencia elérésének érdekében. Ugyanakkor kiemeljük a fokozottan megbízhatatlan adatokat szolgáltató adatgyüjtő folyamatokat, melyek automatizálása instabilitást okozhat a felépítendő nyilvántartásban.

\section{Felhasznált eszközök, kísérleti adatok}

Az adatgyüjtési folyamat automatizáltan végrehajtható lépéseihez egy grml Live Linux disztribúció felhasználásával végezzük. A számítógépet az említett operációs rendszerrel indítjuk el, majd - az indítási folyamat részeként - személyre szabott parancsfájlokkal (script) gyüjtjük össze a szükséges, automatizáltan vagy félig automatizáltan megszerezhető adatokat. A parancsfájlokat bash és gawk környezetben írtuk meg. Egy szöveges üzemmódú felhasználói felület jelzi az adatgyüjtési folyamat elörehaladását, mely szükség esetén lehetőséget nyújt új határérték-adatok bevezetésére. A határértékekről a későbbiekben lesz még szó. Az adatok feldolgozását és standardizálását első lépésben a Live CD végzi. A rendszer esetünkben hálózaton keresztül kapcsolódik egy Microsoft SQL szerverhez, és bevezeti a kapott információkat. A folyamat végén a számítógép leáll. Az adatbázisba bevezetett paraméteradatok felülvizsgálatát és kibővítését egy felhasználók által használt Borland Delphi környezetben megírt szoftver teszi lehetővé. Ennek végeredménye egy végleges bejegyzés az adatbázis egy másik táblájába, mely minden szükséges információt tartalmaz, a tartalmi és formai követelményeknek megfelelően.

A nyilvántartás müködésének jelenlegi fázisában 136701 számítógép állapotleíróinak adatai állnak rendelkezésünkre a paraméterosztályozási folyamat finomítása érdekében. A közölt százalékos adatok magukba foglalják a számítógépek módosításából származó állapotváltozásokat is (pl. hangkártyák, optikai egységek utólagos kiszerelése), ezért a statisztikai hibahatár esetenként elérheti az 5\%-ot is.

$\mathrm{Az}$ állapotparaméter-adatok megszerzésének alapfeltétele, hogy a vizsgált számítógép, valamint annak komponensei legyenek kompatibilisek a felhasznált Linux disztribúcióval. Az modernebb komponensek felismerése érdekében a Linux disztribúciót folyamatosan frissíteni kell. Ennek ellenére a felhasznált módszerek túlnyomó többsége implementált standardok alapján működik, így, amennyiben a gyártók a standardnak megfelelően programozzák ezeket, a generikus információkat, melyek a nyilvántartás létrehozásához és fenntartásához szükségesek, meg lehet szerezni.

\section{3. Állapotleíró paraméterek kivá- lasztása}

Egy személyi számítógépnek valamennyi jellemzője egy állapotleíró paraméter értékével adható meg. A hardver-adatok, specifikációk összegyüjtésekor két megközelítés lehetséges, az egyik a teljes megszerezhető információmennyiség formai megkötések nélkül, illetve az elöre kiválasztott paraméterlista lekérdezése, kitöltése. Az [1] és [3] tanulmányoknak megfelelöen kijelenthető, hogy az aktuális projekthez szükséges állapotleíró paraméterek meghatározása nem zárja ki egyes értékek szükségességének utólagos felismerését. Így a paraméterek kiválasztását követően hasznos 
lehet eltárolni egy nem szürt információhalmazt is, melyből utólag további információk nyerhetőek ki a rendszer állapotáról. $\mathrm{Az}$ információhalmaz elemzésével újabb lehetőségek nyílhatnak további automatizálási lehetőségek felismeréséhez. Jelen tanulmányban egy személyi számítógép hardver-paramétereinek regisztrálhatóságát vizsgáljuk A kiválasztott lista nem teljes, ennek ellenére - az általánosság kizárása nélkül - a segítségével leírható egy személyi számítógép valamint komponenseinek fizikai állapota.

\section{Automatizáltan regisztrálható állapotleíró paraméterek}

Vekov és Pokorádi [1] alapján automatizáltan regisztrálható állapotjelzők, melyek emberi beavatkozás nélkül beszerezhetőek illetve standardizálhatóak. Ennek megfelelően a vezetékes hálózati csatlakozási lehetőség és a vezeték nélküli hálózati csatlakozási lehetőség jelenléte azonosítható az lspci segédprogram felhasználásával. Ez a program azonosítja a PCI sínen elhelyezkedő eszközöket, majd a pci.ids adatbázis [5] helyi másolatából lekérdezi az eszköz funkcionális kategóriáját és a gyártó által adott elnevezéseket. Az említett két eszköztípus funkcionális kategóriája minden esetben tartalmazza a „LAN”, „Ethernet” vagy „Wireless” kulcsszavakat, így ezek jelenléte garancia az eszköz jelenlétére a számítógépben. A már nyilvántartásba vett 136701 számítógép adatai között csak 67 esetben történt manuális változtatás a hálózati eszköz jelenlétét illetően $(0.049 \%)$, ami az adatok helyességét alátámasztani tünik. Ugyancsak az lspci utasítással ellenőrizhető a hangkártya jelenléte valamely számítógépben, ezek esetében a funkcionális kategóriája vagy a leírás tartalmazza az „audio” kulcsszót. Az eddigi eredmények szerint 434 esetben történt manuális állapotváltoztatás, ami a vizsgált rendszerek $0.317 \%$-át teszik ki. Ritkán fordulnak elö, de a firewire
(IEEE 1394) vezérlők is kimutathatók a PCI síneken található eszközök lekérdezésével.

Ugyancsak automatizáltan regisztrálható osztályba sorolható az optikai egységek képességeinek felmérése. A grml Linux operációs rendszer minden optikai egység részére létrehoz képességenként egy kezelőegységet, így a DVD olvasók, melyek képesek CD-t is olvasni, két különbözö kezelöt kapnak: /dev/cdrom és /dev/dvd. A kezelők listáját a hwinfo segédprogram segítségével lehet lekérdezni, „--cdrom” paraméterezéssel. Az optikai egységek esetében $5.121 \%$ utólagos változtatás figyelhető meg. A merevlemezek sorozatszáma az fentebb említett hwinfo ,---hdd" paraméterezésével egyértelmủen meghatározhatóak.

A számítógépben található memóriamodulok mérete szintén automatizáltan regisztrálható paraméterként osztályozható, mivel az SMBIOS táblákban található információk, ha a típusát nem is, de a méretet pontosan tartalmazzák. A kimutatások szerint $16.53 \%$-os a manuális változtatások száma, az adat viszont nem olyan releváns, mint az előzőek, figyelembe véve, hogy a számítógépek megközelítőleg 19\%-ában memóriacserét hajtanak végre.. A felhasználók visszajelzése szerint a memóriaméret felismerése illetve kiszámolása pontos az SMBIOS adatok alapján.

\section{Félig automatizáltan regisztrál- ható állapotparaméterek}

Ebbe az osztályba tartozik a számítógép-merevlemezek méretének, valamint a processzorok sebességének meghatározása. A merevlemezek mérete az LBA méret alapján számolható ki az LBA*512 byte képlet alapján. Mivel az LBA ugyanazon méretek esetében is modellenként változik, egy intervallumhatáros módszer segítségével diszkretizálhatóak a méretek $[1,4]$. Az így kapott merevlemezméretek pontosan megfelelnek a standard kategóriáknak. Hasonló módon kezeljük a processzorok se- 
bességét, melyek teljes kapacitáson is ingadozást mutatnak a nominális sebességhez képest. Például egy $2.53 \mathrm{GHz}$-es processzor valós sebessége a már nyilvántartásba vett gépek esetében $2517 \mathrm{MHz}$ és $2545 \mathrm{MHz}$ közötti intervallumban mozog. A merevlemezekhez hasonlóan ebben az esetben is lehetőséget kell biztosítani az adott nominális sebességhez tartozó intervallum kibővítésére az automatizált folyamatot megszakítva, így a továbbiakban újra automatizáltan regisztrálhatóvá válik az állapotjelző. A processzorsebességek lekérdezése a /proc/cupid rendszerállomány tartalmának elemzésével valósul meg. Ugyanitt a „Gyártó-Család-Modell-Stepping-CPU stringCache memória" értékhatos, mely a kísérletek alapján egyértelmüen azonosít egy processzort (a gyártók nem ismerik el ezt a tényt) [4]. Ennek nyilvántartásba vételével az adott processzor a továbbiakban ismertnek tekinthető, tehát regisztrálása és specifikációinak megadása automatizáltan is megvalósítható.

\section{Manuálisan regisztrálható álla- potparaméterek}

A kizárólag manuálisan regisztrálható paraméterek közül kiemelhetjük a RAM memória típusát. Habár a standardnak megfelelöen meghatározott kitöltendő adatszerkezetek állnak a gyártók rendelkezésére, ezek az információk 88.278\%-ban bizonyulnak hiányosnak vagy tévesnek. Az egyetlen módszer, mellyel meghatározható egy memória típusa a direkt módon történő sebességtesztelés, ami nem megbízható. Jelenleg az egyetlen pontos módszert a közvetlen vizuális megfigyelés biztosítja. Hasonlóképpen megbízhatatlan adat a rendszer sorozatszáma (hiányos vagy helytelen SMBIOS adatok) és a videokártya memóriájának automatizált lekérdezése is. Az utóbbi sok esetben nem rendelkezik saját memóriával, viszont a rendszer RAM memóriájában lefoglalt területeket dedikáltnak mutatja. A megfigyelt manuális módosítások $7.839 \%$-ot tesznek ki.

Manuálisan regisztrálható ugyanakkor a forma, a szín, a funkcionális állapot és a létező csatlakozók (soros, párhuzamos), mivel ezek az információk nem lekérdezhetőek, vagy, az előbbiekhez hasonlóan nem megbízható adatok [1].

\section{Következtetések}

A dolgozatban bemutatott esettanulmány igazolhatja a paraméter-szétválasztás általunk javasolt formájának hasznosságát. Az adatminőség és adatbiztonság alapján minden paraméter meghatározott kategóriába sorolható. Ugyanakkor a már létező statisztikai eredmények hiányának pontosabb tervezést kell maga után vonnia, ennek ellenére egy megalapozott elméleti és gyakorlati áttekintés lehetővé teszi a paraméterek empirikus ismeretek nélküli kezdeti szétválasztását. Mint az általunk bemutatott példa is igazolja, a paraméterek automatikus regisztrálhatósága egy folyamatosan változó kérdéskör, melyet időről időre felül kell vizsgálni hatékonyabb megoldások kidolgozása érdekében.

\section{Szakirodalmi hivatkozások}

[1] Vekov, G., Pokorádi L.: Technikai rendszerek állapotleirásának kérdései, XV. Müszaki Tudományos Ülésszak, EME, Kolozsvár, 2015

[2] Pokorádi, L.: Rendszerek és folyamatok modellezése, Campus Kiadó, Debrecen, 2008., ISBN 978-963-9822-06-1, 8. oldal.

[3] Vekov, G.: Kétszintes információs rendszerek számitógépek nyilvántartásában, Erdélyi Magyar Müszaki Tudományos Társaság, Müszaki Szemle 58, 2012, 43-48.

[4] Vekov G., „Számítógépek és hardverkomponensek. Tesztelés és nyilvántartás", Babeș-Bolyai Tudományegyetem, Kolozsvár, 2008., diplomamunka

[5] The PCI ID Repository, http://pciids.sourceforge.net, Letöltés dátuma: 2015. január 30. 